\title{
PENGARUH PEMBERIAN PAKAN DEDAK PADI TERFERMENTASI CAIRAN RUMEN TERHADAP KUALITAS FISIK DAGING AYAM
}

\author{
Effect of Rice Bran Fermented with Rumen Liquid Addition in Feed on Physical \\ Quality of Broiler Meat \\ Rahmaniar Abdia ${ }^{1}$ ), Djalal Rosyidi ${ }^{2}$ ), and Irfan Djunaidi ${ }^{3}$ )
}

\begin{abstract}
1) Student of Animal Technology Product, Animal Husbandry, Brawijaya University, Malang 65145, Indonesia 2) Lecturer of Animal Technology Product, Animal Husbandry, Brawijaya University, Malang, 65145, Indonesia 3) Lecturer of Animal Technology Product, Animal Husbandry, Brawijaya University, Malang, 65145, Indonesia E-mail:niarabdia04@gmail.com
\end{abstract}

Diterima 31 Mei 2017, diterima pasca revisi 10 Juli 2017 Layak terbit 1 April 2017

\section{ABSTRACT}

The purpose of this research was to determine the effect of fermented rice bran fermented with rumen fluid addition in feed on physical quality of broiler meat. The material used in this research was 20 broiler chest meats taken from broiler that weren't differentiated by gender and maintained for 35 days. The research was done by feeding trial designed with Complete Randomized Design (CRD) with 5 treatments and 4 replications consisting of P0: basal feed (mixture of concentrate, rice bran, and yellow corn), P1: basal feed and rice bran fermented with rumen liquid 2.5\%, P2: basal feed and rice bran fermented with rumen liquid 5\%, P3: basal feed and rice bran fermented with rumen liquid 7.5\%, and P4: basal feed and rice bran fermented with rumen liquid 10\%. If there was a difference between treatments, tested by Duncan's Multiple Range Test (DMRT). The variables measured were meat tenderness, $p H$, and water holding capacity (WHC). The results of this study indicated that the addition of rice bran fermented with rumen liquid in broiler feed showed significantly different effect on meat

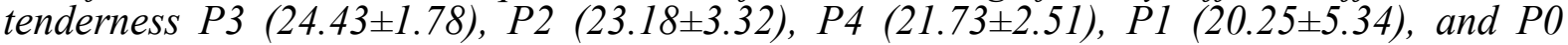

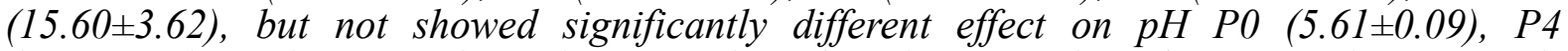

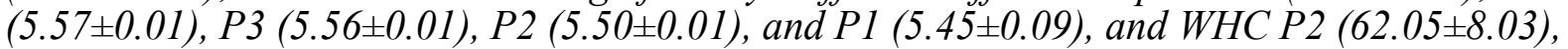

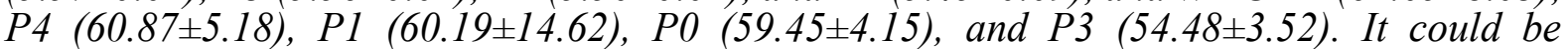
concluded that feed with the $7.5 \%$ level of rice bran fermented with rumen liquid (P3) in broiler feed showed the best results on physical quality of broiler meat.

Key words: Physical meat quality, rice bran, broiler, rumen liquid

\section{PENDAHULUAN}

Daging ayam merupakan salah satu bahan pangan asal ternak yang banyak diminati oleh masyarakat Indonesia. Selain mengandung banyak nutrisi, daging ayam juga tergolong relatif murah dibandingkan dengan daging lain. Daging ayam yang memiliki kualitas baik didapatkan dengan cara tatalaksana pemeliharaan ternak yang baik pula. Salah satu faktor pemeliharaan ternak yang paling mempengaruhi di samping genetik adalah pemberian pakan.

Dedak padi merupakan bahan pakan yang populer digunakan sebagai campuran dalam pakan unggas karena selain ketersediannya yang melimpah dan kontinyu juga karena harganya yang murah dan belum bersaing dengan bahan baku yang lain dalam penggunaannya, serta bahan bakunya yang mudah didapat. Penggunaan dedak padi dalam campuran pakan perlu dibatasi karena dedak padi memiliki serat yang tinggi. Menurut Hartadi dkk, (2005) dedak padi memiliki kandungan serat kasar sebesar 6-12\%. Kandungan serat kasar yang tinggi dan adanya senyawa anti nutrisi tertentu menyebabkan kecernaan dan ketersediaan zat-zat makanan menjadi rendah. Batasan 
penggunaan dedak padi dalam campuran pakan ayam pedaging adalah $10 \%$. Nilai biologis dedak padi dapat ditingkatkan yaitu dengan cara menurunkan kandungan serat kasar yang terkandung dalam bahan tersebut. Hal ini dilakukan karena apabila kandungan serat kasar dalam dedak tinggi maka akan menimbulkan gangguan kecernaan terutama pada proses penyerapan asam amino dan mineral dalam saluran pencernaan ayam pedaging. Gangguan ini akan menyebabkan daging yang dihasilkan memiliki kualitas yang tidak maksimal. Masalah ini dapat diatasi dengan cara melakukan fermentasi terhadap dedak padi tersebut. Salah satu bahan yang dapat digunakan sebagai inokulum dalam proses fermentasi dedak padi adalah cairan rumen sapi.

Cairan rumen sapi yang diperoleh dari rumah potong hewan, selain mengandung mikroba rumen dan enzimenzim yang disekresikan oleh mikroba rumen, juga mengandung zat-zat makanan hasil perombakan mikroba rumen dan enzim, serta vitamin-vitamin dan mineralmineral yang larut dalam cairan rumen yang dapat digunakan sebagai sumber asam amino, vitamin dan mineral untuk meningkatkan kualitas pakan ternak (Budiansyah, Resmi, Nahrowi, Wiryawan, Suhartono, dan Widiastuti, 2011).

Fermentasi ini dilakukan untuk menurunkan kandungan serat kasar dalam dedak padi. Menurunnya kandungan serat kasar tersebut diharapkan dapat meningkatkan nilai konsumsi nutrisi lain seperti protein pada ayam pedaging sehingga kemampuan protein untuk mengikat air dalam daging meningkat dan nilai Water Holding Capacity-nya pun meningkat. Nilai WHC daging tersebut berbanding lurus dengan nilai $\mathrm{pH}$, sehingga apabila nilai $\mathrm{WHC}$ naik maka nilai $\mathrm{pH}$-nya pun akan naik pula. Kemampuan protein untuk mengikat air dalam daging ini juga mempengaruhi kekuatan jaringan ikat pada daging. Semakin tinggi kemampuan protein dalam mengikat air maka semakin mudah jaringan ikat protein pada daging untuk terdegradasi sehingga daging yang dihasilkan akan semakin empuk. Berdasarkan hal tersebut, maka dilakukan penelitian mengenai pengaruh fermentasi dedak padi dengan cairan rumen terhadap kualitas fisik daging ayam yang meliputi $\mathrm{pH}$, keempukan, dan WHC.

\section{MATERI DAN METODE}

Penelitian ini dilaksanakan pada
bulan Mei sampai Juli 2014 di Laboraturium Lapang Sumber Sekar, Batu untuk pemeliharaan ayam pedaging, Laboratorium Nutrisi dan Pakan Ternak Fakultas Peternakan Universitas Brawijaya Malang untuk pengujian bahan pakan, serta Laboratorium Teknologi Hasil Ternak Fakultas Peternakan Universitas Brawijaya untuk pengujian kualitas fisik daging ayam.

Materi penelitian yang digunakan yaitu sampel daging ayam dada sebanyak 20 buah yang diberi pakan perlakuan dedak padi terfermentasi cairan rumen sapi yang diambil dari Rumah Potong Hewan (RPH), dengan nilai koefisien keragaman bobot badan sebesar 9,8099\%. Pakan perlakuan diberikan pada fase finisher dengan campuran jagung, konsentrat, dedak, dan dedak padi terfermentasi.

Dedak padi terfermentasi cairan rumen yang digunakan yaitu dengan perbandingan $300 \mathrm{ml}$ cairan rumen per $\mathrm{kg}$ dedak padi dan penyimpanan selama 72 jam. Pakan perlakuan terdiri dari campuran jagung kuning sebanyak $60 \%$ dan konsentrat sebanyak $30 \%$ dengan persentase pemberian antara dedak dengan dedak terfermentasi yang berbeda. Berikut adalah perbandingan perlakuan pakan yang digunakan pada penelitian ini: 
- $\mathrm{P} 0=$ pakan basal (campuran jagung kuning, konsentrat, dan dedak padi)

- $\mathrm{P} 1$ = pakan basal dengan campuran dedak padi terfermentasi $2,5 \%$

- $\mathrm{P} 2$ = pakan basal dengan campuran dedak padi terfermentasi $5 \%$

- $\mathrm{P} 3$ = pakan basal dengan campuran dedak padi terfermentasi 7,5\%

- $\mathrm{P} 4$ = pakan basal dengan campuran dedak padi terfermentasi $10 \%$
Metode penelitian yang digunakan adalah Rancangan Acak Lengkap (RAL) dan analisis Uji Jarak Berganda Duncan's (UJBD) untuk variabel yang memberikan hasil berpengaruh nyata. Penelitian ini menggunakan 5 perlakuan dan 4 ulangan.

\section{HASIL DAN PEMBAHASAN}

Hasil penelitian pemberian pakan dedak padi terfermentasi cairan rumen terhadap kualitas fisik daging ayam yang meliputi $\mathrm{pH}$, keempukan, dan WHC secara lengkap dapat dilihat pada Tabel 1.

Tabel 1. Pengaruh Pemberian Pakan Dedak Padi Terfermentasi Cairan Rumen terhadap Kualitas Fisik Daging Ayam.

\begin{tabular}{|c|c|c|c|c|c|}
\hline \multirow[t]{2}{*}{ Variabel } & \multicolumn{5}{|c|}{ Perlakuan } \\
\hline & P0 & P1 & $\mathrm{P} 2$ & P3 & $\mathrm{P} 4$ \\
\hline $\mathrm{pH}$ & $5,61 \pm 0,09$ & $5,45 \pm 0,09$ & $5,50 \pm 0,01$ & $5,56 \pm 0,01$ & $5,57 \pm 0,01$ \\
\hline $\begin{array}{c}\text { Keempukan } \\
\text { (N) }\end{array}$ & $15,60^{\mathrm{a}} \pm 3,62$ & $20,25^{\mathrm{b}} \pm 5,34$ & $23,18^{b} \pm 3,32$ & $24,43^{b} \pm 1,78$ & $21,73^{b} \pm 2,51$ \\
\hline WHC (\%) & $59,45 \pm 4,15$ & $60,19 \pm 14,62$ & $62,05 \pm 8,03$ & $54,48 \pm 3,52$ & $60,87 \pm 5,18$ \\
\hline
\end{tabular}

Keterangan: Subskrip yang berbeda pada baris yang sama menunjukkan perbedaan yang nyata $(\mathrm{P}<0,05)$

\section{Pengaruh Perlakuan Terhadap pH}

Hasil analisis ragam menunjukkan bahwa perlakuan pemberian pakan dedak padi terfermentasi cairan rumen memberikan perbedaan yang tidak nyata $(\mathrm{P}>0,05)$ terhadap $\mathrm{pH}$ daging ayam. Daging ayam yang memiliki $\mathrm{pH}$ dari yang tertinggi secara berurutan selama penelitian adalah perlakuan P0 $(5,61 \pm 0,09), \mathrm{P} 4(5,57 \pm 0,01)$, P3 $(5,56 \pm 0,01), \quad$ P2 $(5,50 \pm 0,01), \quad$ dan P1 $(5,45 \pm 0.09)$.

Hasil analisis statistik menunjukkan bahwa pemberian dedak padi terfermentasi cairan rumen pada pakan memberikan perbedaan yang tidak nyata $(\mathrm{P}>0,05)$ terhadap nilai $\mathrm{pH}$ daging ayam. Lawrie (2003) menyatakan bahwa daging postmortem memiliki $\mathrm{pH}$ ultimat normal sekitar 5,5 yang sesuai dengan titik isoelektrik sebagian besar protein daging termasuk miofibril.
Penurunan $\mathrm{pH}$ terjadi karena tertutupnya filamen-filamen myofibril yang terdapat pada protein daging sehingga air yang masuk semakin sedikit. Protein dalam daging tersebut mempengaruhi ion $\left(\mathrm{H}^{+}\right)$ sehingga semakin sedikit protein daging ayam, $\mathrm{pH}$ akan semakin menurun karena rendahnya kemampuan untuk mengikat ion $\left(\mathrm{H}^{+}\right)$.

Menurut Soeparno (2009) peningkatan atau penurunan konsumsi pakan berhubungan dengan kualitas pakan yang tersedia, sehingga dapat mempengaruhi karakteristik atau kualitas daging. Konsumsi pakan juga dapat mempengaruhi $\mathrm{pH}$ daging. Perbedaan nilai $\mathrm{pH}$ dapat menunjukkan bahwa proses glikolisis postmortem berlangsung lebih lambat pada konsumsi pakan konsentrat rendah meskipun $\mathrm{pH}$ ultimat hamper tidak berbeda. Besarnya penurunan $\mathrm{pH}$ otot postmortem dipengaruhi oleh banyak 
faktor, diantaranya faktor intrinsik seperti spesies, bangsa, jenis kelamin, variasi individu ternak, tipe otot daging, glikogen otot dan aktivitas enzim yang mempengaruhi glikolisis, serta faktor ekstrinsik seperti temperatur, kelembaban, stress, dan obat-obatan (Soeparno, 2009).

$$
\text { Salah satu faktor yang }
$$

mempengaruhi perubahan nilai $\mathrm{pH}$ setelah proses pemotongan diantaranya adalah kandungan asam laktat yang terdapat dalam otot, kandungan glikogen, dan penanganan sebelum penyembelihan. Hal ini didukung oleh pendapat dari Purnomo (2012) bahwa kenaikan $\mathrm{pH}$ daging diakibatkan penurunan aktivitas mikroba penghasil asam karena persediaan glikogen yang semakin berkurang. Prayitno, Suryanto, dan Zuprizal (2010) menjelaskan bahwa penggunaan pakan yang memiliki kandungan energi tinggi dapat mempengaruhi kadar glikogen pada otot ayam pedaging sehingga dapat mempengaruhi nilai $\mathrm{pH}$ daging.

\section{Pengaruh Perlakuan Terhadap Keempukan}

Hasil analisis ragam menunjukkan bahwa perlakuan pemberian pakan dedak padi terfermentasi cairan rumen memberikan perbedaan yang nyata $(\mathrm{P}<0,05)$ terhadap keempukan daging ayam. Daging ayam yang memiliki nilai keempukan dari yang tertinggi secara berurutan selama penelitian adalah perlakuan P3 $(24,43 \pm 1,78), \quad \mathrm{P} 2$ $(23,18 \pm 3,32), \quad \mathrm{P} 4 \quad(21,73 \pm 2,51)$, P1 $(20,25 \pm 5,34)$, dan P0 $(15,60 \pm 3,62)$.

Hasil analisis statistik menunjukkan bahwa pemberian dedak padi terfermentasi cairan rumen pada pakan memberikan perbedaan yang nyata $(\mathrm{P}<0,05)$ terhadap nilai keempukan daging ayam. Hasil perhitungan berdasarkan Uji Jarak Berganda Duncan (UJBD) menunjukkan bahwa perlakuan level dedak padi terfermentasi cairan rumen terhadap keempukan daging ayam yang memberikan nilai tertinggi adalah perlakuan dengan level pemberian $7,5 \%$ (P3). Hasil uji menunjukkan bahwa daging dengan nilai keempukan terbaik adalah perlakuan dengan level pemberian dedak padi terfermentasi sebesar $0 \%$ (P0). Hal tersebut dapat disebabkan oleh kurang maksimalnya penyerapan nutrisi dedak padi terfermentasi oleh ayam pedaging.

Daging yang semakin empuk disebabkan oleh menurunnya kadar serat pada pakan yang diberikan, sehingga lemak menjadi lebih mudah larut. Hal ini sesuai dengan pernyataan dari Soeparno (2009) bahwa kandungan pakan yang berkualitas akan berpengaruh terhadap keempukan daging. Level protein yang meningkat pada pakan akan memicu pertumbuhan, dan pertumbuhan yang cepat akan meningkatkan terbentuknya lemak daging. Otot daging mengandung kolagen yang merupakan protein structural pokok pada jaringan ikat dan mempunyai pengaruh besar terhadap keempukan daging. Perlakuan dengan jumlah penambahan dedak padi terfermentasi sebesar $10 \%$ (P4) seharusnya menunjukkan hasil dengan nilai keempukan terbaik karena kandungan seratnya paling rendah. Hasil penelitian menunjukkan bahwa P4 justru memiliki nilai keempukan yang cenderung tinggi atau alot. Hal ini dapat disebabkan oleh banyaknya pergerakan yang dilakukan ternak sebelum dan pada saat pemotongan. Soeparno (2009) menjelaskan bahwa ternak yang banyak bergerak pada saat pemotongan akan menghasilkan fase kekakuan yang lebih cepat diikuti dengan pemendekan otot yang relative lebih besar. Otot yang berkontraksi atau memendek menjelang rigormortis akan menghasilkan daging dengan panjang sarkomer yang pendek, lebih banyak mengandung kompleks aktomiosin atau ikatan antar filamen, sehingga daging menjadi kurang empuk. Ditambahkan pula oleh Suryanata (2014) bahwa keempukan daging tidak hanya dipengaruhi oleh pakan yang diberikan saja namun banyak faktor lain yang mempengaruhinya seperti faktor antemortem yaitu genetik, bangsa, dan fisiologi, faktor umur, manajemen 
pemeliharaan, jenis kelamin, dan spesies. Keempukan daging juga dapat dipengaruhi oleh rigormortis daging yang terjadi setelah ternak dipotong (Winarno, dkk., 1980).

Menurut Soeparno (2009) lemak intramuskuler ikut berperan dalam membentuk keempukan daging karena lemak akan larut di antara ikatan serabut otot daging yag menghasilkan daging yang lebih empuk dan lebih berair. Penyebab utama kealotan pada daging karena terjadinya pemendekan otot pada saat proses rigormortis sebagai akibat ternak yang terlalu banyak bergerak pada saat pemotongan (Lawrie, 2003). Soeparno (2009) menyatakan bahwa $\mathrm{pH}$ mempengaruhi keempukan daging. Daging dengan $\mathrm{pH}$ tinggi mempunyai keempukan yang lebih baik daripada daging dengan $\mathrm{pH}$ rendah.

\section{Pengaruh Perlakuan Terhadap WHC}

Hasil analisis ragam menunjukkan bahwa perlakuan pemberian pakan dedak padi terfermentasi cairan rumen memberikan perbedaan yang tidak nyata $(\mathrm{P}>0,05)$ terhadap WHC daging ayam. Daging ayam yang memiliki WHC dari yang tertinggi secara berurutan selama penelitian adalah perlakuan P2 $(62,05 \pm 8,03), \quad \mathrm{P} 4 \quad(60,87 \pm 5,18), \quad \mathrm{P} 1$ $(60,19 \pm 14,62)$, P0 $(59,45 \pm 4,15)$, dan P3 $(54,48 \pm 3,52)$.

Hasil analisis statistik menunjukkan bahwa pemberian dedak padi terfermentasi cairan rumen pada pakan memberikan perbedaan yang tidak nyata $(\mathrm{P}>0,05)$ terhadap nilai WHC daging ayam. Hasil tersebut menunjukkan bahwa perlakuan sebesar 5\% (P2) merupakan perlakuan dengan nilai WHC tertinggi dan terbaik.

Pemberian dedak padi terfermentasi dalam pakan ayam pedaging bertujuan untuk menurunkan kadar serat yang terkandung dalam dedak padi. Menurunnya kadar serat tersebut menyebabkan nilai WHC daging ayam yang semakin meningkat. Semakin tinggi nilai WHC maka semakin baik pula kualitas dari suatu daging.
Hal ini sejalan dengan pendapat Wismer-Pedersen (1971) bahwa Water Holding Capacity dipengaruhi oleh pakan, spesies, umur, temperatur, kelembaban, penyimpanan, jenis kelamin, kesehatan, perlakuan sebelum pemotongan dan lemak intramuskuler. Adapun kecenderungan penurunan WHC ini berhubungan dengan kandungan serat kasar yang tinggi sedangkan standar kebutuhan serat kasar ayam pedaging berkisar antara 3-5\%. Kandungan serat kasar yang terlalu tinggi di dalam pakan menyebabkan pakan tidak dapat dicerna sehingga dapat membawa zat makanan yang dapat dicerna ikut keluar dengan feses (Wahyu, 1997). Parakkasi (1990) menyatakan bahwa kandungan serat kasar dalam pakan yang meningkat dapat menyebabkan daya cerna menurun sehingga ayam pedaging kurang mampu memanfaatkan zat makanan. Daging dengan kadar lemak yang tinggi akan memiliki nilai WHC yang tinggi, begitupun sebaliknya, daging dengan kadar lemak yang rendah memiliki nilai WHC yang rendah pula (Soeparno, 2009).

Abustam (2004) menambahkan bahwa daya ikat air juga dipengaruhi oleh $\mathrm{pH}$, pada $\mathrm{pH}$ yang lebih tinggi dari $\mathrm{pH}$ isoelektrik protein daging, sejumlah muatan positif dibebaskan dan terdapat surplus muatan negatif yang mengakibatkan penolakan dari mikrofilamen dan memberi lebih banyak ruang untuk molekul air, semakin banyak molekul air dalam daging maka WHC akan meningkat. Otot dengan kandungan lemak intramuscular yang tinggi cenderung mempunyai nilai WHC yang tinggi. Hubungan antara lemak intramuscular dengan WHC adalah kompleks. Lemak intramuscular melebarkan mikrostruktur daging, sehingga memberi lebih banyak kesempatan pada protein daging untuk mengikat air (Hamm, 1986). 
Nilai WHC pada daging dipengaruhi oleh susunan jarak molekul dari protein miofibril terutama miosin dan serabut-serabut (filament - filamen). Kekuatan tarik - menarik antara molekulmolekul yang berdekatan dapat mengalami penurunan, yang disebabkan oleh kenaikan muatan netto negatif di antara muatan protein atau melemahnya ikatan hidrogen. Akibat dari proses tersebut adalah jaringan protein akan membesar, pembengkakan meningkat, dan lebih banyak air yang terikat oleh protein sehingga akan mengakibatkan peningkatan nilai WHC. Kekuatan tarik-menarik antara molekulmolekul yang berdekatan bila mengalami kenaikan, maka air yang terikat akan dilepaskan kembali, sehingga nilai WHC turun (Hamm, 1986).

\section{KESIMPULAN}

Pemberian dedak padi terfermentasi cairan rumen pada level pemberian sebanyak $7,5 \%$ pada pakan ayam pedaging memberikan hasil terbaik terhadap nilai kualitas fisik daging ayam.

\section{SARAN}

Saran yang dapat diberikan berdasarkan penelitian ini yaitu perlu dilakukan penelitian lebih lanjut mengenai pengaruh pemberian dedak padi terfermentasi cairan rumen terhadap variabel yang berbeda seperti mikrobiologi daging.

\section{DAFTAR PUSTAKA}

Abustam, E. 2004. Bahan Ajar Ilmu dan Teknologi Pengolahan Daging. Fakultas Peternakan. Universitas Hasanuddin, Makassar.

Budiansyah., Resmi., Nahrowi., K.G. Wiryawan., M.T. Suhartono dan Y. Widyastuti. 2011. Hidrolisis Zat Makanan Pakan oleh Enzim Cairan Rumen Sapi Asal Rumah Potong Hewan. Agrinak. Vol. 01 No.1 September 2011: 17-24.

Hamm, R. 1986. Functional Properties of the Myofibril System and Their Measurement in Muscle as Food. Academic Press. New York.

Hartadi, H., S. Reksohadiprojo, dan A.D. Tilman. 2005. Tabel Komposisi Pakan untuk Indonesia. Cetakan Keempat. Gadjah Mada University Press. Yogyakarta.

Lawrie, R.A. 2003. Ilmu Daging. Edisi Ke5. Diterjemahkan oleh Parakkasi, A., dan Y. Amwila. Univeristas Indonesia Press, Jakarta.

Parakkasi, A. 1990. Ilmu Gizi dan Makanan Monogastrik. Angkasa. Bandung.

Prayitno, A.H., E. Suryanto dan Zuprizal. 2010. Kualitas Fisik dan Sensoris Daging Ayam Broiler yang Diberi Pakan dengan Penambahan Ampas Virgin Coconut Oil (VCO). Buletin Peternakan. Vol. 34 (1):55-63.

Purnomo, H. 2012. Teknologi Hasil Ternak Kaitannya dengan Keamanan Pangan Menjelang Abad 21. Fakultas Peternakan. Universitas Brawijaya, Malang. 
Soeparno. 2009. Ilmu dan Teknologi Daging. Cetakan kelima. Gajah Mada University Press, Yogyakarta.

Suryanata, I.K. 2014. Pengaruh Penambahan Xilanase dalam Pakan dengan Level Dedak yang Berbeda Terhadap Kualitas Fisik Daging Ayam Pedaging. Malang. Fakultas Peternakan Universitas Brawijaya.

Wahyu, J. 1997. Ilmu Nutrisi Unggas. Edisi Keempat. Universitas Gadjah Mada Press, Yogyakarta.

Winarno, F.G., S. Fardiaz, dan D. Fardiaz. 1980. Pengantar Teknologi Pangan. Penerbit PT. Gramedia. Jakarta.

Wismer-Pedersen, J. 1971. The Science of Meat and Meat Products. 2nd ed. Ed. J.F. Price san B.S. Schweigert. W.h. Freeman and Co., San Fransisco. Page 177. 